Announcement

\title{
CALL FOR PAPERS: CHILDREN AND THE LAW
}

Law and Human Behavior invites manuscript submissions for a special section/ issue on children and the law. Much work is currently in process regarding numerous issues of relevance to psychology, law, and children. We are seeking articles, both empirical and theoretical, that will increase our knowledge base in this area. Suggested general topics include but are not limited to: juvenile delinquency, child abuse and neglect, custody, adoption, children's capacities, institutionalization of children, and foster care. More specific issues would be: psychological assumptions underlying Supreme Court cases regarding children's rights, the impact of reporting laws on the prevention of child abuse, adolescent competency to make critical decisions independent of parents. In essence, we believe that encouragement should be given to our readership to pursue these topics, and we would like to increase submissions on children's issues to Law and Human Behavior.

Deadlines for submission of completed manuscripts is February 1, 1991. Send original and two copies of the completed manuscript to:

N. Dickon Reppucci, Associate Editor

Law and Human Behavior

Department of Psychology

Gilmer Hall

University of Virginia

Charlottesville, VA 22903

Standard manuscript submission requirements for Law and Human Behavior should be followed. 